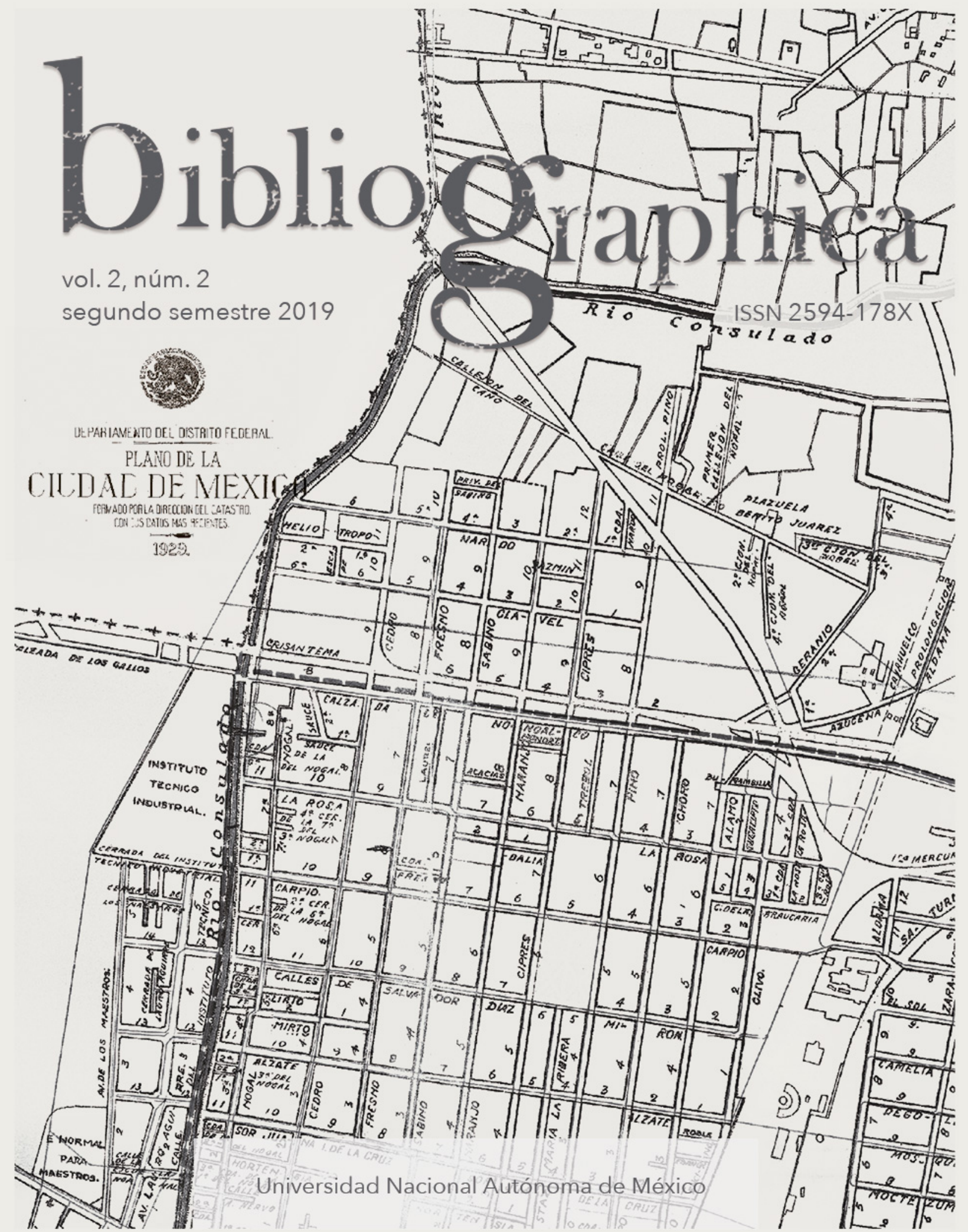




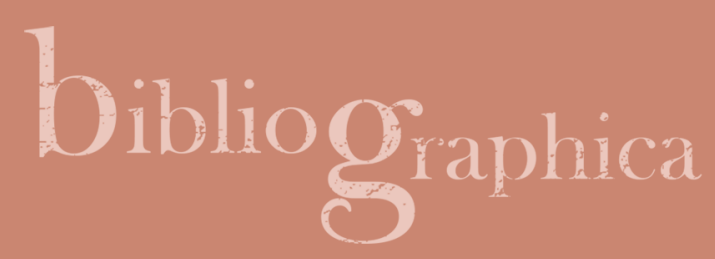

\section{Un subterfugio editorial mexicano del siglo XVII: la edición contrahecha de la viuda de Bernardo de Calderón}

A Mexican Editorial Subterfuge of the $17^{\text {th }}$ Century:
The Misshapen Edition of Bernardo de Calderón's Widow

Arturo Villasana Baltazar

villasana.baltazar@gmail.com

Guadalupe Rodríguez Domínguez

guadalupe.dominguez@uaslp.mx

Universidad Autónoma de San Luis Potosí

Facultad de Ciencias Sociales y Humanidades

Recepción: 24.01.2019 / Aceptación: 07.05.2019

DOI: https://doi.org/10.22201/iib.bibliographica.2019.2.36 
Resumen Uno de los principales retos de la historia del libro mexicano es proporcionar datos fehacientes que permitan disminuir inconsistencias y vacíos de información, tan comunes en esta área de estudio. El esfuerzo realizado aquí se encamina, justamente, a atender una de esas fisuras historiográficas: se trata de explicar la posible génesis de la edición mexicana ilegal titulada De la devoción y patrocinio de San Miguel, príncipe de los ángeles, antiguo tutelar de los godos y protector de España, impresa en México a mediados del siglo XVII por Paula de Benavides, viuda de Bernardo de Calderón.

Palabras Imprenta manual; ediciones ilegales; edición contrahecha; mujeres impresoras; clave siglo XVII.

Abstract One of the biggest challenges of Mexican book history is to provide reliable data in order to reduce inconsistencies and information gaps, so common in this field of study. The aim of the present paper is to fill in, precisely, one of those historiographical gaps: a possible explanation about the genesis of the illegal Mexican edition titled De la devoción y patrocinio de San Miguel, príncipe de los ángeles, antiguo tutelar de los godos y protector de España, printed in Mexico towards the mid $17^{\text {th }}$ Century by Paula de Benavides, Bernardo de Calderón's widow.

Keywords Manual press; illegal editions; misshapen edition; women printers; $17^{\text {th }}$ Century. 


\section{Introducción}

La primera prensa instalada en territorio continental americano fue la de Nueva España, en 1539, bajo el auspicio del obispo fray Juan de Zumárraga y por encargo de Juan Cromberger, impresor sevillano que designaría a Juan Pablos como regente. Fermín de los Reyes Gómez señala que el contrato celebrado entre ambos el 12 de junio de dicho año establece que Pablos debía obtener una licencia del obispo de México para sacar a la luz cada edición, siguiendo la disposición de 1502, tal como se aplicaba en Sevilla:

ytem que cualquier libro o otras cosas qualesquier que se ynprimieren en la dha cibdad de Mexico se ynpriman con licençia del obispo de Mexico conforme a las prematicas destos reynos y no en otra manera y que con fin de cada libro se ponga fue ynpreso en la çibdad de Mexico en casa de Juan Corenverguer y que no ponga nombre ni de otra persona alguna. ${ }^{1}$

El primer intento por regular la producción de las imprentas fue la Pragmática, dirigida a impresores y libreros, que los reyes católicos expidieron el 8 de julio de 1502 en la ciudad de Toledo y que establece la obligación de someter los originales a censura previa, lo cual consistía en que antes de que un libro pudiera ser comercializado, hacía falta tener una licencia de impresión. ${ }^{2}$ Utrera Bonet explica que la Pragmática establecía además la división del territorio y de las instituciones que participaban en la censura, las cuales serían las autoridades religiosas -arzobispo y obispo- y las civiles - presidentes de audiencias-. ${ }^{3}$ Los problemas que generaban la impresión y comercialización de libros en España no fueron resueltos con esta medida, así que en 1558 Felipe II decretó otra Pragmática, la de mayor importancia para la regulación del libro español, que establecía lo siguiente:

\footnotetext{
${ }^{1}$ Fermín de los Reyes Gómez, El libro en España y América: legislación y censura, siglos XV-XVIII (Madrid: Arco/Libros, 2000), 175.

${ }^{2}$ María del Carmen Utrera Bonet, "La pragmática del 1558 sobre impresión y circulación de libros en Castilla a través de los fondos de la Biblioteca de la Universidad de Sevilla", en Funciones y prácticas de la escritura: I Congreso de Investigadores Noveles en Ciencias Documentales, coord. de Juan Carlos Galende Díaz (Madrid: Universidad Complutense de Madrid, 2013), 278.

${ }^{3}$ lbid.
} 
Al principio de cada libro así impreso ha de ponerse:

- La licencia

- La tasa

- El privilegio, si lo hubiere

- El nombre del autor

- El nombre del impresor y lugar de impresión. ${ }^{4}$

Si bien los libros impresos en España no siempre siguieron estas reglas, la mayoría se ajustaba a lo establecido por el rey Felipe II, así pues, no es extraño que los preliminares legales aparecieran en libros americanos en fechas muy cercanas a la publicación de la Pragmática. Justamente en 1558 fue impreso en México por Juan Pablos el Thesoro spiritual en lengua de Mechuacán, ${ }^{5}$ de fray Maturino Gilberti, que cumplía con algunos puntos importantes de la regulación del libro establecida por Felipe II; a partir de ese año otorgarían las licencias el virrey y el arzobispo, y se reproducirían junto con las aprobaciones y correcciones de los censores e inquisidores. Este procedimiento primero fue seguido en Nueva España y luego se extendió por el resto de los territorios americanos. ${ }^{6}$

Además, como indican Aguilera y Martínez, en Nueva España la Iglesia y la Corona españolas siempre tuvieron gran preocupación porque no se leyeran o poseyeran libros sospechosos o heréticos, especialmente los relacionados con la Reforma protestante. Para dicho fin se valieron de diversas legislaciones, por ejemplo el primer Concilio Mexicano de 1555, "en su capítulo setenta y cuatro, determinaba que cualquier libro que se publicara o se quisiera introducir, fuera visto de antemano y examinado por la autoridad eclesiástica". ${ }^{7}$ Lo anterior con la intención de expurgar el contenido "peligroso". Más tarde la legislación del III Concilio Mexicano de 1585, que adaptó los cánones del Concilio de Trento, estableció que la autoridad eclesiástica ordinaria examinara y aprobara los libros para imprimir, circular, comprar o vender. ${ }^{8}$

La censura del libro durante el virreinato siempre fue una de las mayores preocupaciones de la Iglesia y la Corona; como menciona José Abel Ramos So-

\footnotetext{
${ }^{4}$ Reyes Gómez, El libro en España y América, 199.

${ }^{5}$ Ibid., 176.

${ }^{6}$ lbid., 207.

7 Ramón Aguilera Murguía y Xóchitl Martínez Barbosa, "Libros, inquisición y devoción", en Inquisición novohispana, vol. 33, ed. de Noemí Quezada, Martha Eugenia Rodríguez y Marcela Suárez (México: UNAM, 2000), 362.

8 Ibid., 363.
} 
riano respecto al reino español, en 1554 se establecieron dos tipos de censura para el libro, una previa y otra posterior:

La primera estuvo a cargo de la autoridad civil y la segunda bajo el cuidado del Tribunal del Santo Oficio de la Inquisición. Desde entonces, el gobierno civil se enfocó principalmente a la revisión del texto para, en su caso, otorgar la licencia de impresión; el manuscrito debía llevar también la licencia eclesiástica cuando se trataba de obras de materia religiosa. La Inquisición, por su parte, se encargó sobre todo de la censura después de la publicación. ${ }^{9}$

De acuerdo con el investigador, desde el siglo XVI las medidas de control y las penas se volvieron muy severas, a tal grado que "imprimir sin licencia significaba la pena de muerte, la pérdida de los bienes y la quema de los libros, y aquel que modificara textos ya examinados y aprobados era amenazado con la pérdida de sus bienes y el exilio perpetuo"; sin embargo, el mismo autor aclara que "en la Nueva España una reglamentación tan minuciosa normó todos los ámbitos propios al circuito del libro: impresión, difusión y lectura, pero se centró principalmente en el segundo y tercero de estos aspectos". ${ }^{10}$ Así, la Inquisición novohispana persiguió sobre todo al libro por su contenido como objeto peligroso para la Iglesia y la Corona, lo cual permitió que las personas relacionadas con estos libros: impresores, libreros, mercaderes, lectores, no siempre recibieran un castigo, como deja constancia el mismo Ramos Soriano en Los delincuentes de papel: Inquisición y libros en la Nueva España (1571-1820), con información extraída de documentos inquisitoriales.

Aunque los impresores o tipógrafos "en general no fueron objetivo directo del Tribunal, llegaron a ser amenazados con penas severas, que consistían en el pago de 100 pesos y la excomunión mayor", por ejemplo, en el caso de José Bernardo de Hogal y "los demás [impresores] de la ciudad [de México]", ${ }^{11}$ con la obra Devoción de Santa Gertrudis a la pasión de Cristo Nuestro Señor.

\footnotetext{
9 José Abel Ramos Soriano, Los delincuentes de papel: Inquisición y libros en la Nueva España (1571-1820) (México: FCE, 2011), 38.

10 lbid., 39, 90.

11 Ibid., 185.
} 


\section{Hallazgo de una edición sospechosa}

Dentro del proyecto "Imprenta y Literatura en el Virreinato de la Nueva España, Siglos XVI y XVIII12 se localizó un impreso del siglo XVII sacado a la luz por la imprenta de Paula de Benavides, viuda de Bernardo de Calderón, en México y sin año de publicación, titulado De la devoción y patrocinio de San Miguel, príncipe de los ángeles, antiguo tutelar de los godos y protector de España: en que se proponen sus grandes excelencias, y títulos que hay para implorar su patrocinio, cuyo autor fue el padre Juan Eusebio Nieremberg. Esta edición no se encuentra registrada en La imprenta en México (1539-1821) de José Toribio Medina, en el apartado dedicado al siglo XVII.

El catálogo Nautilo de la Biblioteca Nacional de México (BNM) registra un ejemplar de esta edición con la signatura RSM 1643 M4NIE, que indica 1643 como año de impresión y aclara que el dato fue sacado de las licencias. Además de éste se localiza otro en la Biblioteca Newberry de Chicago, con la signatura topográfica Ayer 657,65 .N67 1643, también con 1643 como año de impresión, pero sin especificar de dónde se extrajo dicha información. La Bancroft Library de Berkeley posee uno más con la signatura x F1207.N33, y registra 1643 como año de publicación, pero no da más especificaciones al respecto. Por último, la Biblioteca Nacional de Chile registra un ejemplar con signatura E.G. 4-40(16), cuyo año de impresión se especifica como 1700, sin ofrecer mayores datos.

La divergencia en el año de impresión por parte de unas bibliotecas, la ausencia de información sobre la asignación del año en otras y la omisión del impreso por parte de Medina revelan que el libro de Nieremberg era problemático. Uno de los objetivos del proyecto de investigación mencionado -en el cual se inscribe este trabajo- es la elaboración de un Repertorio de impresos mexicanos del siglo XVII, cuya metodología rigurosa exige la comprobación y cotejo de los datos editoriales de los impresos respecto a la información ofrecida por la tradición bibliográfica, así como la asignación de datos editoriales a los impresos sine notis o carentes de año de impresión. En este sentido, es necesario mencionar que ya se habían encontrado discrepancias entre la información que ofrecen los catálogos de algunas bibliotecas y la que contienen los impresos. ${ }^{13}$

\footnotetext{
12 Proyecto desarrollado en la Universidad Autónoma de San Luis Potosí, con financiamiento Prodep (SEP), Convenio DSA/103.5/15/6988.

${ }^{13}$ En el catálogo de la BNM está registrado con la signatura local 615 LAF un volumen facticio que contiene, entre otros, la Libra astronómica de Sigüenza y Góngora (1690), y el Discrrso etheorologico del nuevo cometa, visto en aqueste hemisferio mexicano; y gene-
} 
En vista de estas circunstancias, fue necesario ampliar la indagación, y así se obtuvieron los resultados que se detallan a continuación.

Andrade, en su Ensayo bibliográfico mexicano del siglo XVII, asigna el número 277 al texto De la devoción y patrocinio de San Miguel impreso por Paula de Benavides, y proporciona la siguiente explicación sobre el año de publicación:

Dicha viuda de Calderón comenzó a publicar desde 1640 a 1670; como una de las censuras tiene la fecha de 1642, este opúsculo parece debe colocarse en este año de 1643, pues es probable que al año de censurado viniese ya a Nueva España para que se procediera a la impresión. Además, en el catálogo de libros vendidos en París, 1869, que fueron del P. Fischer, n. 1243, se le asigna el dicho año de $1643 .^{14}$

Resulta pertinente hacer algunas aclaraciones sobre la afirmación de Andrade: primero, la viuda de Calderón regentó la imprenta de 1641 a $1684^{15} \mathrm{y}$ segundo, y más importante, ninguno de los preliminares de dicho libro está fechado en 1642. Las tres fechas que aparecen son de marzo y abril de 1643. Aunque no hemos localizado el mencionado catálogo de libros vendidos en París de 1869, queda evidenciada la poca fiabilidad de los datos proporcionados por Andrade.

Es importante aclarar que si bien Medina no registra el impreso en el año $1643 \mathrm{ni}$ en todo el periodo 1601-1700, sí lo hace en el anexo dedicado a los impresos "Sin fecha determinada" del siglo XVII, con el número 1 945: por Nie-

ralmente en todo el mundo este año de 1625..., ambos impresos por Paula de Benavides, viuda de Calderón; ahora bien, se ha comprobado que el título en el impreso realmente dice "año de 1652", por lo que evidentemente el título registrado por el catálogo de la biblioteca es una errata, quizá debido a un error de lectura o de dedo al momento de capturar la información.

${ }^{14}$ Vicente de Paula Andrade, Ensayo bibliográfico mexicano del siglo XVII (México: Imprenta del Museo Nacional, 1899), 226.

${ }^{15}$ Como lo demuestra el mismo Medina en su Imprenta en México con el registro de los impresos sacados a la luz por Paula de Benavides, que van precisamente de 1641 a 1684. Aunque después, repitiendo la información de Andrade sobre la posible asignación del año de la edición De la devoción y patrocinio de San Miguel, dice que Benavides terminó de imprimir en 1670. Al respecto Yolanda Bello Fuentes, en su tesis de maestría "Impresores y sus obras en el siglo XVII: Bernardo Calderón y Paula de Benavides, viuda de Bernardo Calderón, 1631-1684" (UNAM, 2011), 9, también cita el trabajo de Medina para establecer 1641-1684 como el periodo de actividad de Paula de Benavides. 
remberg, P. Juan Eusebio, De la devoción y patrocinio de San Miguel, y en dicho registro explica:

No estoy de acuerdo en este punto con mi sabio amigo [Vicente de Paula Andrade], pues siendo todos los preliminares de 1643, Marzo y Abril, es muy difícil que en ese mismo año haya podido llegar el libro a México y ser reimpresas las 300 páginas, más o menos, de que consta. En todo caso ha debido salir a la luz la edición mexicana antes de 1670, fecha en que concluye de imprimir la viuda de Calderón. ${ }^{16}$

Medina, con esta acertada reflexión, alude a los preliminares de una edición española de la misma obra. Por lo visto, anteriormente el impreso de la viuda de Calderón presentaba interesantes irregularidades producto de los datos ofrecidos por las bibliotecas que resguardan algunos ejemplares y los registrados por la tradición bibliográfica, y el asunto se complicó aún más con la localización de la edición señalada por Medina. Edición casi idéntica a la de Paula de Benavides, con el mismo título y autor pero salida a la luz en Madrid, de la imprenta de María de Quiñones en 1643, uno de cuyos ejemplares se conserva en la Biblioteca Histórica de la Universidad Complutense de Madrid "Marqués de Valdecilla" (signatura BH FLL 2989).

Presentamos enseguida las descripciones tipobibliográficas de ambas ediciones, donde se advierten las coincidencias y diferencias, así como sus respectivas portadas (Imágenes 1 y 2).

De acuerdo con los preliminares de la edición española, en 1643 el padre Juan Eusebio Nieremberg recibió en Madrid las licencias requeridas para imprimir su libro titulado De la devoción y patrocinio de San Miguel, y fue la imprenta madrileña de María de Quiñones ${ }^{17}$ la elegida para sacar a la luz dicha

\footnotetext{
16 José Toribio Medina, La imprenta en México (1539-1821), t. III (Santiago de Chile: En casa del autor, 1907), 288.

17 Quiñones perteneció a un linaje de impresores, al igual que Paula de Benavides; su primera relación con la imprenta fue a raíz de su casamiento con Pedro Madrigal, hijo del impresor homónimo y María Rodríguez Rivalde. De este matrimonio enviudó entre 1603 y 1604, año en que volvió a casarse, esta vez con Juan de la Cuesta, según información de Juan Delgado Casado, Diccionario de impresores españoles (siglos XV-XVII), vol. 2 (Madrid: Arco/Libros, 1996), 566. Sin embargo, Davinia Rodríguez Ortega señala que aún hay duda de si dicho Pedro Madrigal sería realmente hijo de María Rodríguez (viuda de Pedro Madrigal) o de un hermano de éste, pues llegó a firmar como "P. de Madrigal [si firma no tiene el de] ynpresor de libros por sí y por María Rodríguez, su tía", véase "Herede-
} 


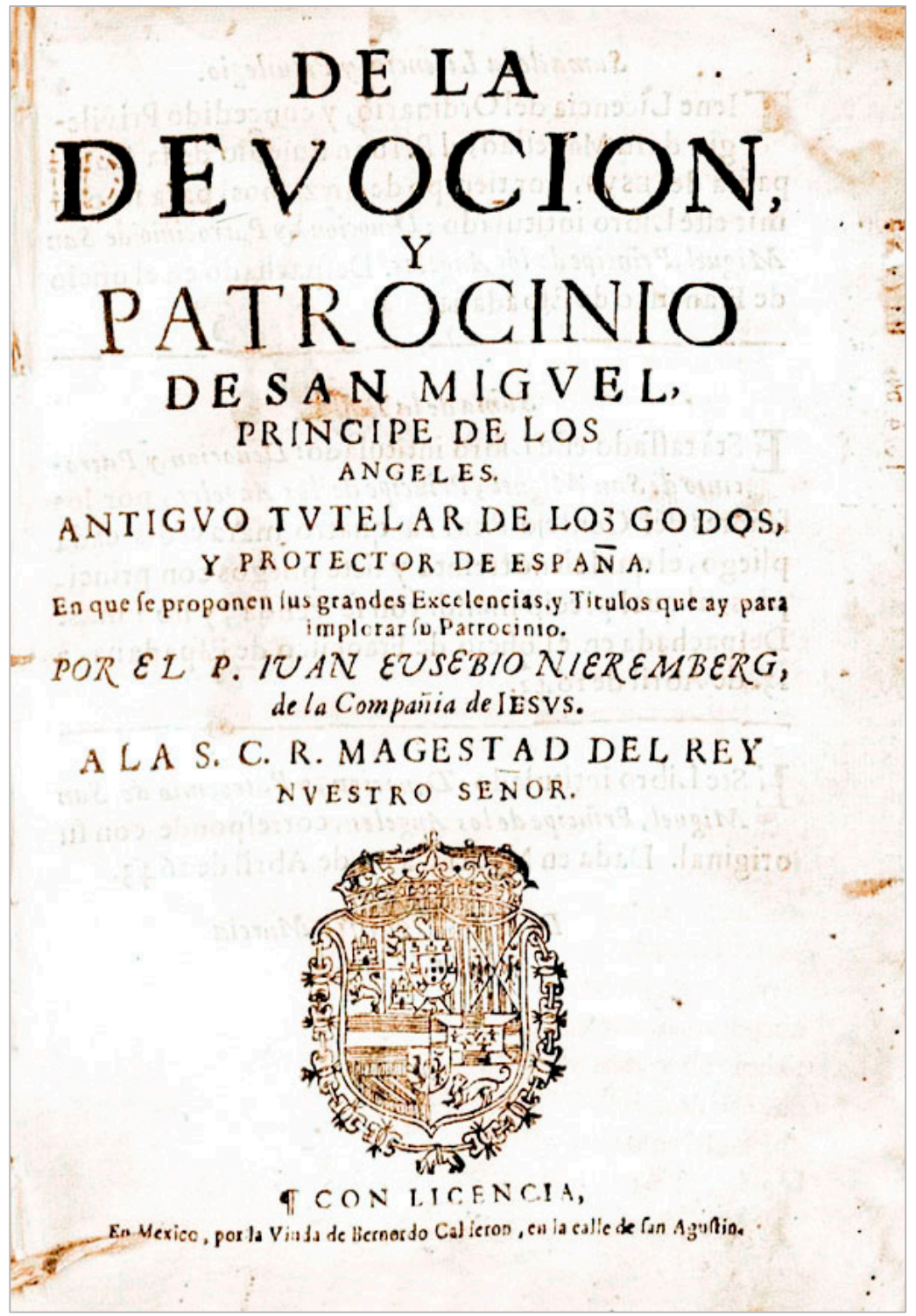

Imagen 1. Juan Eusebio Nieremberg, De la devoción y patrocinio de San Migvel, príncipe de los ángeles, antiguo tutelar de los godos y protector de España, impreso por Paula de Benavides, ca. 164?, portada. Obras Antiguas, Raras, Biblioteca Nacional de México (BNM). 
Nieremberg, Juan Eusebio: De la devoción y patrocinio de San Migvel, príncipe de los ángeles... En México, por la viuda de Bernardo Calderón. [Sin información sobre el año, ca. 164?].

$4^{\circ}$.- [ ] $]^{4}$ १-१११ A-R ${ }^{8}$.- 12 h., 1-272 pp.- Letra redonda y cursiva.- Compuesto por 37 pliegos.

Tipos de 7 fundiciones: c. 250 R (portada), c. $200 \mathrm{R}$ (portada), c. $150 \mathrm{R}$ (portada), c. $115 \mathrm{C}$ (titulillos y encabezamientos interiores), $117 \mathrm{R}$ (texto), $83 \mathrm{C}$ (apostillas marginales), $82 \mathrm{R}$ (apostillas marginales).

Sin marcar los lugares correspondientes a $h$. con sign.: ๆ2, ११2, A4, B4, C4, D4, E4, F4, G4, H4, 14, K4, L4, M4, N4, O4, P4, Q4, R4.

Erratas en paginación: 153 (en lugar de 133), 186 (168), 259 (257).

Iniciales grabadas.- Titulillos.- Con reclamos.Apostillas marginales.

[ ]1 r: Portada:

DE LA | DEVOCION, | Y | PATROCINIO | DE SAN MIGVEL, | PRINCIPE DE LOS | ANGELES, | ANTIGVO TVTELAR DE LOS GODOS, | Y PROTECTOR DE ESPAÑA. | En que e proponen \us grandes Excelencias, y Titulos que ay para | implorar |u Patrocinio. | POR EL P. IUAN EUSEBIO NIEREMBERG, | de la Compañia de IESVS. | A LA S. C. R. MAGESTAD DEL REY | NVESTRO SEÑOR. |[Grab. xil. de escudo de armas de Felipe $\mathrm{V} \mid \boldsymbol{\eta}$ CON LICENCIA, | En Mexico, por la Viuda de Bernordo [sic] Calderon, en la calle de $\lceil$ an Aguftin.

[ ]1 v: Licencia y privilegio por 10 años despachados en el oficio de Francisco de Espadaña: Suma de la Licencia, y Priuilegio. | $\left(\mathrm{T}^{2}\right)$ lene Licencia del Ordinario y concedido Privile- | gio de \u Mage $\{$ tad, el P. Iuan Eu |ebio de la Com- I pañia de IESVS, por tiempo de diez años, para impri- | mir elte Libro intitulado: Deuocion...

[ ]1 v: Tasa despachada en el oficio de Francisco de Espadaña a 13 de abril de 1643: Suma de la Ta||a.| $\left(E^{2}\right)$ Stà ta $\int\left\lceil\right.$ ado e $\int$ te Libro intitulado: Deuocion, y Patro- | cinio de San Miguel, Principe de los Angeles, por los | | eñores del Con [ejo Real, à quatro maravedis cada | pliego, el qual tiene treinta y |iete pliegos con princi- | pios...

[ ]1 v: Cotejo de la obra con el original, dado en Madrid a 13 de abril de 1643 por el doctor Francisco Murcia de la Llana: ( $\left.E^{2}\right)$ Ste Libro intitulado: Deuocion, y Patrocinio de San / Miguel, Principe de los Angeles, corre [ponde con |u | original. Dada en Madrid, à 13. de Abril de 1643.

[ ]2 r: Censura firmada en Madrid por Juan de Cantabrana el 28 de marzo de 1643: CENSURA DEL P. M. Fr. IUAN DE | Cantabrana, Calificador del Con $\mid$ ejo Supremo, Procurador Ge-l neral en las Prouncias de Elpaña, por el Reuerendilsimo P. | General de $\{u$
Religion, y Mini itro del Conuento de la / Santi [sima Trinidad de Madrid. | $\left(\mathrm{P}^{3}\right) \mathrm{OR}$ comi $\int$ sion del 个eñor $\mathrm{D}$. Gabriel de Aldama, | Teniente de Vicario general de la Villa de Ma- | drid, he vifto vn Libro intitulado: Deuocion, y Pa- | trocinio de [an Miguel...

[ ]2 v: Aprobación eclesiástica firmada por el padre Agustín de Castro en el Colegio Imperial de la Compañía de Jesús a 8 de abril de 1643: APROUACION DEL P. AGUSTIN DE / Caltro, de la

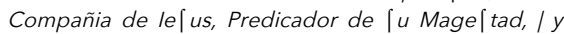
Cathedratico en I us E[tudios Reales / de [ta Corte. / $\left(\mathrm{H}^{3}\right)$ E vi to por orden de V. A. el Libro de las Ex- | celencias del Arcangel |an Miguel, que ha e $\int-\mid$ crito el P. Iuan Eu febio, y hallado en èl ven- | cida la mayor dificultad que es hablar acertadamente | de vna co |a tan retirada de los $\lceil$ entidos...

[ ]3 r-9 v: Dedicatoria al Rey de España: [Tres líneas de adornos tipográficos] A LA S. C. R. MAGESTAD | DEL REY NVESTRO | SEÑOR. | SEÑOR. | $\left(B^{6}\right)$ ASTANTEMENTE | tiene |ignificado la | Providencia divina | con felici [simos [u- | ce | | os, y fau | tos dias | १2 r-११ v: Justificación de la obra: RAZON DESTE LIBRO | A LOS REYNOS DE ESPAÑA. | (L $\left.{ }^{5}\right)$ AS gracias que dava à la naturaleza | Socrates, por aver nacido en Grecia, | y de [pues de [to en Atenas, las doy | yo por aver nacido en $E[$ paña...

[११2] r-v: Carta del Consejo firmada en Madrid a 17 de marzo de 1643: CARTA DEL CONSEJO DE SU Mage $\mid$ tad, à todas las Ciudades de $\mid$ tos $\mid$ Reynos. | $\left(\mathrm{S}^{5}\right) \mathrm{V}$ Mage [tad, Dios le guarde, con el cui- | dado que fiempre tiene del bien publi- | co, y de $\lceil$ can $\lceil o$ de $\lceil$ us va [ [allos, ha [oli- | citado...

[ๆๆ3] r-११४ v: Indice: | TABLA DE LOS CAPITVLOS | de $\left\{\right.$ te Libro. | $\left(\mathrm{C}^{2}\right)$ Ap. I. Entre los demas Angeles, $\{e$ deue princi- / palmente venerar [an Miguel. pag. I. | Cap. 2. Del admirable Nombre del Arcangel |an Mi- / guel. pag. 10. |... ....... [ remate en el birlí con las iniciales "IHS" al centro].

p. 1-272: Texto dividido en 28 capítulos: [ Tres líneas de adornos tipográficos y "(可)" al centro de la segunda línea] DE LA | DEVOCION, | Y PATROCINIO DE | SAN MIGVEL, PRINCIPE | DE LOS ANGELES, POR SVS | GRANDES EXCELENCIAS. | ? CAPITVLO I. ? | Entre los demas Angeles |e deue principalmente | venerar San Miguel. | $\left(E^{4}\right) L$ celebrar à los Angeles, no es |olo | honra \uya, 〔 ino gloria de Dios, y | mucho provecho nue $\lceil$ tro. Porque | como dize San Buenaventura...

Ejemplar descrito: México. Biblioteca Nacional. RSM 1643 M4NIE. 


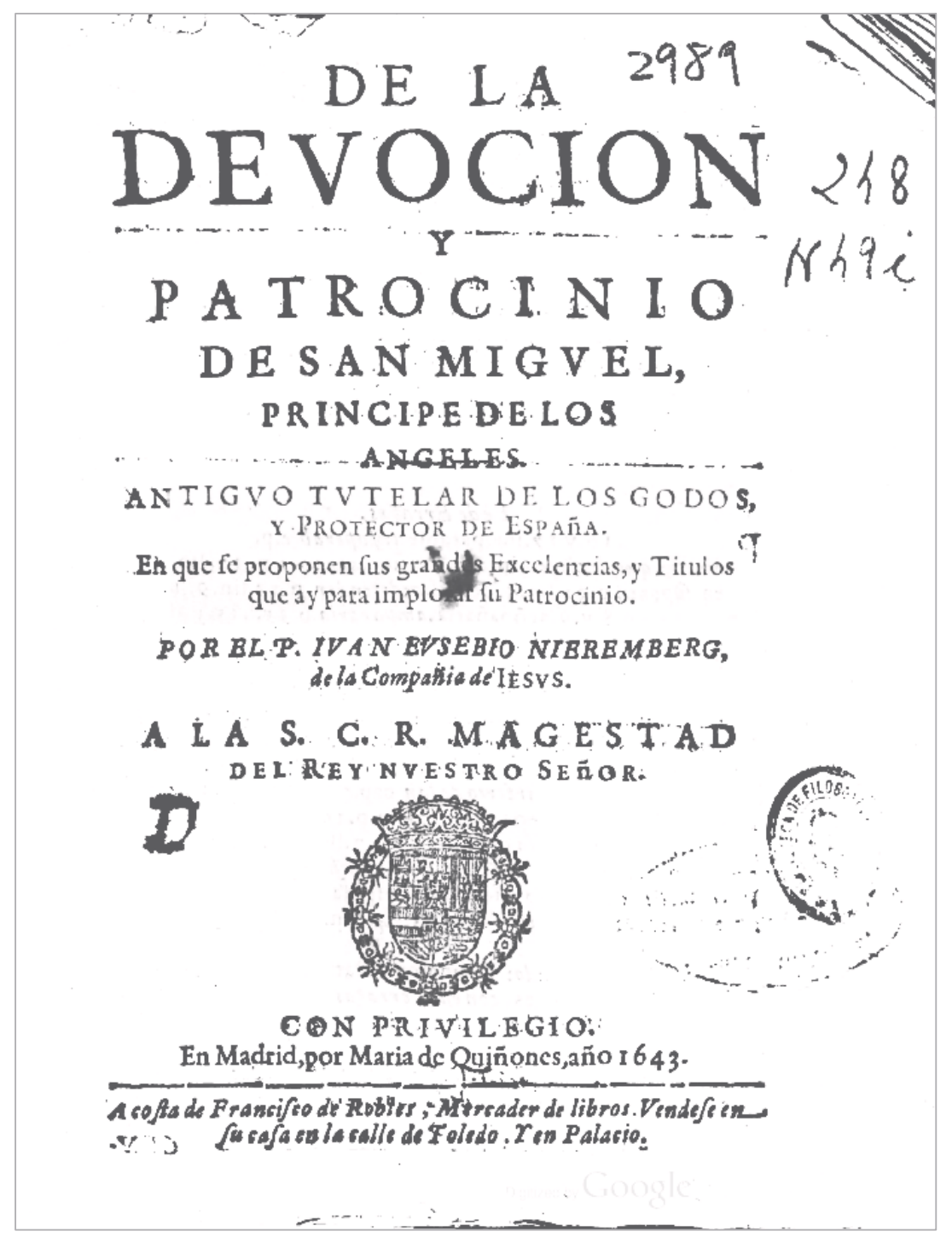

Imagen 2. Nieremberg, De la devoción y patrocinio de San Migvel, príncipe de los ángeles, antiguo tutelar de los godos y protector de España, impreso por María de Quiñones, 1643, portada. Biblioteca Histórica Fondo Antiguo, Universidad Complutense de Madrid. 
Nieremberg, Juan Eusebio: De la devoción y patrocinio de San Migvel, príncipe de los ángeles... En Madrid, por María de Quiñones, año 1643. A costa de Francisco Robles, mercader de libros. Véndese en su casa en la calle de Toledo y en Palacio.

$4^{\circ}$.- 18 १ा 4 A-R8.- 12 h., 1-272 pp.- Letra redonda y cursiva- Compuesto por 37 pliegos.

Tipos de 7 fundiciones: c. $280 \mathrm{R}$ (portada), $130 \mathrm{R}$ (preliminares), c. $130 \mathrm{C}$ (titulillos), $116 \mathrm{R}$ (texto), $116 \mathrm{C}$ (tabla ), $84 \mathrm{R}$ (apostillas marginales), $84 \mathrm{C}$ (apostillas marginales).

Iniciales grabadas.- Titulillos.- Con reclamos.Apostillas marginales.

[I] r: Portada:

DE LA | DEVOCION | Y | PATROCINIO | DE SAN MIGVEL, | PRINCIPE DE LOS | ANGELES | ANTIGVO TVTELAR DE LOS GODOS, I Y PROTECTOR DE ESPAñA. | En que le proponen |us grandes Excelencias, y Titulos | que ay para implorar [u Patrocinio. | POR EL P. IVAN EVSEBIO NIEREMBERG, | de la Compañia de lesvs. | A LA S. C. R. MAGESTAD | DEL REY NVESTRO SEÑOR. | [Grab. xil. de escudo de armas de Felipe V | CON PRIVILEGIO. | En Madrid, por Maria de Quiñones, año 1643. | [Línea de filete simple ocupando el ancho de la hoja] / A co [ ta de Franci [co de Robles, Mercader de libros. Vende le en / I u cala en la calle de Toledo. Y en Palacio.

I v: Licencia y privilegio por 10 años, despachados en el oficio de Francisco de Espadaña: Suma de la Licencia, y Priuilegio. | $\left(T^{2}\right)$ lene licencia del Ordinario, y concedido Priuilegio de $[\mathrm{u} \mid$ Mage $[$ tad el Padre luan Eu |ebio de la Compañia de lesvs, | por tiempo de diez años para imprimir e [te libro intitulado: De-/ uocion...

I v: Tasa despachada en el oficio de Francisco de Espadaña a 13 de abril de 1643: Suma de la Ta|sa.l ( $\left.E^{2}\right)$ Sta tal lado e fte libro intitulado: Deuoción y Patrocinio de / lan Miguel, Principe de los Angeles, por los Señores del Con- | | ejo Real, à quatro marauedis cada pliego, el qual tiene treinta y | | iete pliegos con principios...

I v: Fe de erratas: Fè de Erratas. | $\left(\mathrm{P}^{2}\right) \mathrm{AG}$. 3. lin. 16. y 17. in [eparable, in [uperable. p. 9. li. 8. y 9. que | dixe $\lceil\lceil$ e. que dezir [e, lin. [ilegible] canor, arcaros, p. 12 lin. 19. |e | ponen, |uponen, p. 32, lin. 5. defen $\mid \mathrm{ar}$, defender. p. 33, lin. 9. fumo, el | | umo...

I v: Cotejo de la obra con el original, dado en Madrid a 13 de abril de 1643 por el doctor Francisco Murcia de la Llana: E[ te libro intitulado: Deuocion y Patrocinio de \an Miguel, | Principe de los Angeles, con e $\int$ tas erratas corresponde con su ori- / ginal. Dada en Madrid a 13 de Abril de 1643.

I2 r: Censura firmada en Madrid por Juan de Cantabrana el 28 de marzo de 1643: CENSVRA DEL P. M. F. IVAN DE / Cantabrana, Calificador del Cō ejo Supremo, Pro- / curador General en las Prouincias de
E[ paña, / por el Reuerendi [s. P. General de [u Religion I y Mini tro del Conuento de la Santi lsima / Trinidad de Madrid. / ( $\left.\mathrm{P}^{3}\right)$ OR comi [sion del Señor D. Gabriel de Aldama, | Teniente de Vicario general de la villa de Madrid, | he vi to vn libro intitulado: Deuocion $y$ Patrocinio de / [an Miguel..

१2 v: Aprobación eclesiástica firmada por el padre Agustín de Castro en el Colegio Imperial de la Compañía de Jesús a 8 de abril de 1643: APROVACION DEL P. AGVSTIN / de Caltro, de la Compañia de le lus, Predicador de / | u Mage $\lceil$ tad, y Catedratico en lus E[tudios / Reales de [ta Corte. | $\left(\mathrm{H}^{2}\right)$ E vi $\int$ to por orden de V. A. El libro de las Ex- | celencias del Arcangel [an Miguel, que ha | e [crito el P. Iuan Eu [ebio, y hallado en èl vencida la | mayor dificultad, que es hablar acertadamente de | vna co|a tan retirada de los $\int$ entidos...

१3 r- १5 v: Dedicatoria al Rey de España: [Tres líneas de adornos tipográficos] | A LA S. C. R. MAGESTAD | DEL REY NVESTRO | SEÑOR. | SEÑOR | $\left(B^{6}\right)$ A | tantemente tiene |ignifi- | cado la Prouidencia diuina | con

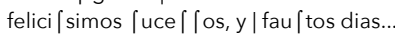

१6 r- ११1 v: Justificación de la obra: RAZON DESTE LIBRO | A LOS REINOS DE ESPAÑA. | (L $\left.{ }^{4}\right)$ As gracias que daua a la naturaleza So- | crates, por auer nacido en Grecia, y de [- | pues de [to en Atenas, las doy yo por | auer nacido en $\mathrm{E}$ [ paña...

११2 r-११12 v: Carta del Consejo firmada en Madrid a 17 de marzo de 1643: CARTA DEL CONSEIO DE / [u Mage [ tad à todas las Ciudades / de [tos Reinos. | $\left(\mathrm{S}^{5}\right) \mathrm{V}$ Mage [tad, Dios le guarde, con el cui- | dado que

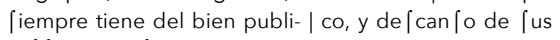
va | [allos, ha [olici- | tado...

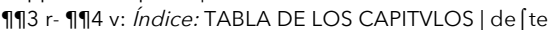
Libro. | $\left(C^{2}\right)$ Ap. I. Entre los demas Angeles se deue principal- / mente venerar [an Miguel. Pag. I. | Cap. 2. Del admirable nombre del Arcangel | an Miguel. / Pag. $10 \ldots|\ldots| \ldots|\ldots|$ [Remate en el birli $]$.

p. 1-272: Texto dividido en 28 capítulos: [Tres líneas de adornos tipográficos] DE LA | DEVOCION, | Y PATROCINIO DE | SAN MIGVEL, PRINCIPE | DE LOS ANGELES, POR SVS | GRANDES EXCELENCIAS. | CAPITVLO I | Entre los demas Angeles \e deue principalmen- / te uenerar [an Miguel. | ( $\left.E^{4}\right) \mathrm{L}$ celebrar à los Angeles no es |olo| honra |uya, |ino gloria de Dios, y mu-| cho prouecho nue $[$ tro. Porque co- $\mid$ mo dize $\lceil$ an Buenaventura...

Ejemplar descrito: Madrid. Universidad Complutense. Biblioteca Histórica "Marqués de Valdecilla". BH FLL 2989. 


\section{Sumadela Licencia, y Prisilegio.}

TYene Licencia del Ocdinario, y concedido Privilegio de fu Mageftad, el P. I uan Eufebio de Ia Compañia de insvs, portiempode diez ańos, para imprimir efte Libro inticulado: Dewocion, y Patrocinio de $S_{a z}$ Miguel, Principe de los Angeles. Defpachado en el oficio de Francifco de Efpadaña.

\section{Sumade lar a fa.}

F Stà tafrado efte Libro intitulado: Deuocion,y Patrocinio de San Miguel, Principe de!los Angeles, por los feńores del Confejo Real, à quatro maravedis cada pliego, el qual ciene treinta y fiete pliegos con principios, al qual precio mandaron fe venda, y no à mas. Defpachada en el oficio de Francilco de Efpadaña, à 13. de Abril der 643 .

Imagen 3. Parte de los preliminares que imprimió la viuda de Calderón en su edición; los apartados tienen una extensión de 6 y 7 líneas, respectivamente.

Nieremberg, De la devoción y patrocinio...,

impreso por Paula de Benavides, ca. 164?, 1 vol. Obras Antiguas, Raras, BNM.

\section{Suma de la Licenci, y Priallegio.}

T I E s licencia del O-dinario, y conced do Prituilegio de fa Mageftad el Padre Inan Eufebio de la Compañia de Iesvss

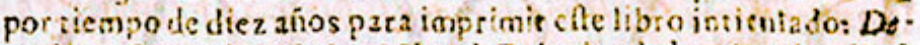
Aosiony Patrocinio de Jan Miguel, Principe,de los Angcies. Defpachado co el oficrode Fr Iikitio de Elpalsña.

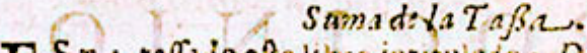

E S r a tafiadoefe libio instulato: Detociong Patrociniod: fan Miguel, Principe de los Angeles por tos Scinores del Con fejo Rea!, a qutcro ma auedis cada pliega, el qual tiene recincs y frete pliegos con principios, al qual precio mandaron fe venday noà mas. D fpuclazda erict oficio de Francifco de Épad ña,â 13 . de Abrilde $16+3$.

Imagen 4. Parte de los preliminares de la edición de María de Quiñones; apartados con extensión de 5 y 6 líneas, respectivamente. Nieremberg, De la devoción y patrocinio..., impreso por María de Quiñones, 1643, 1 vol. Biblioteca Histórica Fondo Antiguo, Universidad Complutense de Madrid. 
obra ese mismo año. El patrocinador de los gastos de la tirada fue Francisco de Robles, mercader de libros que, curiosamente, vendió en su casa también la primera y segunda partes de El ingenioso hidalgo don Quijote de la Mancha de Cervantes - de 1605 y 1615, respectivamente-, impresos por Juan de la Cuesta quien, al contraer matrimonio con María de Quiñones (tras el fallecimiento de su primer marido), pasaría a hacerse cargo de la imprenta que anteriormente era de los Madrigal. Es natural que María de Quiñones, al enviudar de Juan de la Cuesta, mantuviera las relaciones comerciales establecidas por su marido, ${ }^{18}$ como sucedió con el librero Francisco de Robles.

Volviendo a De la devoción y patrocinio de San Miguel, el primer detalle que salta a la vista es el hecho de que existan dos ediciones de la misma obra, y supuestamente del mismo año, en dos lugares separados por tantos kilómetros de mar. La edición elaborada en Nueva España - de acuerdo con Andrade- se llevó a cabo el mismo año de 1643 en la imprenta de Paula Benavides, viuda de Bernardo de Calderón. ${ }^{19}$ Coincidimos al respecto con la mencionada reflexión de Medina acerca de la improbabilidad de dar a la prensa los 37 pliegos de que consta el libro en tan poco tiempo (de mayo-junio a diciembre de 1643, considerando las fechas de los preliminares), ya que además del periodo necesario para la impresión en España, habría que agregar el tiempo que tardarían en llegar las copias del libro a América, y se suma a esto el hecho de que el padre Nierem-

ra de Pedro Madrigal: María de Quiñones, impresora de ingenios áureos", Estudos IberoAmericanos 42, núm. 3 (2016): 1072.

${ }^{18}$ En 1625 terminan las noticias sobre Juan de la Cuesta. Poco después -al parecer en 1627- fallece María Rodríguez Rivalde y a partir de 1628 es cuando inicia realmente la actividad tipográfica de María de Quiñones, quien comienza firmando sus trabajos con el pie de imprenta "Herederos de la viuda de Pedro Madrigal". En 1634, fecha de Avisos del Parnaso de Pérez de Sousa, empieza a figurar el nombre de Quiñones en los impresos, y se mantendrá hasta 1664. Delgado Casado, Diccionario de impresores, 566.

${ }_{19} \mathrm{Sin}$ el respaldo de fuentes documentales, resulta aventurado tratar de encontrar otra relación entre María de Quiñones y Paula de Benavides, además de la coincidencia de que ambas fueron viudas de impresores e imprimieron la obra de Nieremberg, motivo de estas páginas, pero habría que arriesgarse a mencionar que un tal Pedro de Quiñones trabajó en la imprenta de Benavides durante varios años, como dejan constancia algunos impresos: "en casa de la viuda de Calderón, por Pedro de Quiñones". Por otra parte, Pedro Quiñones tuvo un periodo como impresor con su propia prensa. Al respecto, Kenneth C. Ward dice en su tesis doctoral: "There is no clear relationship between María de Quiñones and Pedro de Quiñones, the Mexican printer", véase "Mexico, where They Coin Money and Print Books: The Calderón Dynasty and the Mexican Book Trade, 1630-1730" (tesis de doctorado, Universidad de Texas, 2013), 19 [nota al pie], acceso el 26 de junio de 2019, http://hdl.handle.net/2152/26062. 


$$
\text { de Sail Miguel. Cap. 1. } 3 \text {. }
$$

dotadola de tan gran poder, y virtudde a Serm de Sando Mi. hazermilagros. La qual quifo emplearffe chacle: Quamvis on: en nueftro bien, y provecho, honrandole ximo cí hovore de. con tan grandes favores, y declarādo que beam excoicre, prx: cipuè tamen glocio. chonremos con fingularil simas filsinum Michaeica demonttraciones, y eltupendos prodigios caieftis exercit" pri. que a hecho para eite efecto. matein, \& đucé. Ve.

Por elto reconociendo los Santos, y mem gratiá, prarrio. Doctores efta voluntad de Dios,nos cxor pretivam fingularem, tan à la veneracion, $y$ hóra defte foberano inluperabile in virtve ef piricu. San Laurencio a Iuftiniano dize: ${ }^{t e n}$, conditores be. Aunque deuemos honrar con gran Dencracion nevolentiam, ipfias. tados los de la milecia del cielo; peroprincipal - tantizm, th co camen mence al gloriofi/simofan Migucl fu Capitä, qui ipfuin fecit, $\boldsymbol{\alpha}$ Prumado: beneremas en el Dna gracia fwbleme, b orat de S. Miclszele. una fingular prerrogatina,y minifterio: Dna in. Buic ergofofclpien. Din, \& masimum $p 2$. uperable virtud, y amor del crsador. Panta - tronum potentêque leon Diacono ${ }^{b}$ dizz: Teng amos cfte grandi- di fenforcm,\& liberé, fims Patron, poder ofo defen/or, confiado inter ic confidenter loqué. ceffor para con Dios, fumo Reyde todos, y di- pud ounium Ren a. vino Principe de /a Milicia Miguel, todos de - Deum, diecinum muli. vocamíce le en/alcemos con coracones limpios. mus Miclise habea.

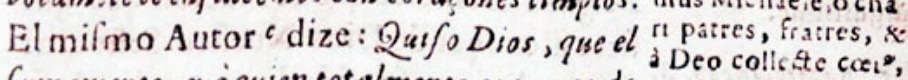
fumamente, y a quien cotalmente oye, yes de pie ipsú fecoper om. todas maniras venerado Miguel Princspe de nes oe reveri purissi. $\begin{array}{ll}\text { A2 } & \text { la mam, in mandiscor. } \\ \text { dibus femp:r magni. }\end{array}$ ficè extollamus. c lbid Summè a dum, \&e nom ex parte veneran dom arilitix Principem Micha!tem, melsorun, \& divinitusinipiratorum, \& fidetísimosum hominum cfie prathem, zoran falutis curam genere voluts.

Imagen 5. Página de la edición mexicana donde se aprecia que desde el inicio del segundo párrafo "Por esto reconociendo" hasta "una in-" (líneas 8-16) el texto se corresponde con el de la madrileña. Nieremberg, De la devoción y patrocinio..., Paula de Benavides, ca. 164?, 3. Obras Antiguas, Raras, BNM. 


$$
\text { defan Miguel. }
$$

der, y vircud de hazer milagros. La qual a Serm de Sǚo Miquifo empleafle en nueftro bien y proue - chacle: Qusavis om cho, honrandole con tan grandes fauores, acs colimilitesmache himo cum honore de y declará jo que quiere le honremos con beam' ixcolere,prx fingularifsimas demunftraciones, y eftu cipuè tamen gloriopend prodigios que filsimunM chä̈lem pendos prodigios que ha hecho para efte coeleftis exercituspri efecto. matem, $\&$ ducé. Ve-

Peremur in illo fubli Por cfto reconociendo los Santos, y mem gुratiā,prarroDoctores efta voluntad de Dios, nos exor- garivam fingularem, Drattirú minilteriü, tan a la veneracion, $y$ hóra defte foberano infuperabilem virzuefpiritu. San Laurencio a Iuftiniano dize: tem, conditoris beAunque deuemos honrar con granveneracion i nevolentism, ipfin:s. Anque dewemoshonrar congranveneracion a que bellatotis confrodos los de la milicia del cielo; pero princtpal tantiam, in eo tamen mente al gloriofisimo fan Miguel fu Capitan, y qui ipfum fecit, \& Primado: veneremos en el una gracia /ublime, borat.de S. Michie vna-ingular prerrogatiwa, $y$ minifterio:vna in. le. Hunc ergo fufcifeparablevirtud, y amor del criador. Pantaleó patronú potentéćá; Diacono $b$ dize: Tengamos efte grandißimo defenforem, \& liberè Patron, poderofo Defenfor, confiado interceffor 2 tem intercefforema. para con Dios,fumo Rei de codos, y diwino Prin. pud omnium Regen cipe de fu milicia Xiguel, todos deuotamente Deum, diuinummilileen alcemos con corasones limpios. El mifmo tra Principem habea Autor c dize: Qviifo Dios que el smaméte, ya à ri patres, fratres, \&e quien totalmente oye, y es de todas maneras ve- pié ipfum femper om nerado Miguel Principe de la milicia cel ffial, nes ve rever à purifsi

$A_{2}$ fuefje dibusfempermagnificè extollamus. clbid Summè autem benediçum, \& vndiạ́; exausiécum, \&comni ex parte venerandum militix Principem Michacl m, meliotvm, \& diuinitus infpiratorum, \& fidelifsímorum hominum elie pr $x$ fídem, \& corum falucis curam getere voluit.

Imagen 6. La edición madrileña presenta el texto y la mexicana trata de ajustarse a él.

Por ejemplo, aquí se lee completo "capitán" y en la otra hay una abreviatura; sin embargo, esto sólo cobra importancia al considerar la obra íntegra. Nieremberg,

De la devoción y patrocinio..., María de Quiñones, 1643, 3.

Biblioteca Histórica Fondo Antiguo, Universidad Complutense de Madrid. 


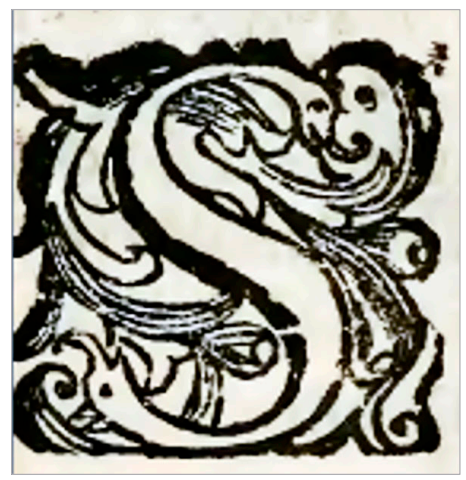

Imagen 7. Inicial grabada "S" de Arte mexicano: se nota una leve fisura debajo del centro. Diego de Galdo Guzmán, Arte mexicano,

Paula de Benavides, 1642, h. sign. *7r. John Carter Brown Library.

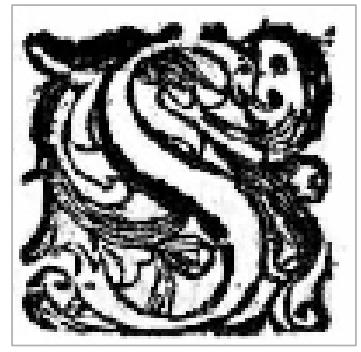

Imagen 8. Inicial grabada "S" de Imagen de la Virgen...: además de la fisura anterior, tiene una en la parte superior. Miguel Sánchez, Imagen de la Virgen..., Paula de Benavides, 1648, h. sign. 3r. Biblioteca Histórica Fondo Antiguo, Universidad Complutense de Madrid.

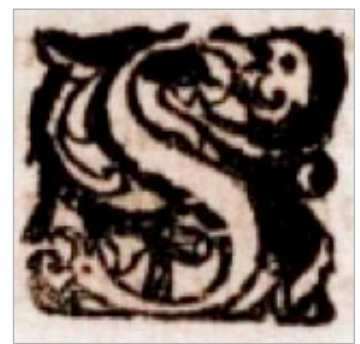

Imagen 9. Inicial grabada "S" en De la devoción y patrocinio...,

muy parecida a la de la Imagen 8 en cuanto a su desgaste. Nieremberg,

De la devoción y patrocinio..., Paula de Benavides, 164?, 164.

Biblioteca Histórica Fondo Antiguo, Universidad Complutense de Madrid. 
berg tenía un Privilegio Real por 10 años para imprimir su libro, así que Paula de Benavides requería de la aprobación del autor para hacer una impresión en regla y no hay indicios de un documento donde el autor pida a la viuda de Calderón hacer esa edición, pues de existir bien podría haberse agregado a los preliminares y no reducirse a copiar los que ya tenía el ejemplar impreso en España.

A simple vista podría decirse que se trata de la misma edición con portada distinta, pero basta observar con detenimiento para descubrir que los impresos, si bien presentan muchas similitudes, no son exactamente iguales. Ambas ediciones están impresas en formato cuarto y conformadas por 37 pliegos, es decir, tienen exactamente el mismo tamaño y extensión, pero las coincidencias van más allá, pues cada una tiene 12 hojas de preliminares y 272 páginas de texto propiamente dicho -aunque la fórmula colacional sí difiera entre cada una-. La primera diferencia notable de contenido, además de las señaladas acerca de la materialidad, es que la edición elaborada en España contiene un pequeño apartado con la "Fe de erratas" en los preliminares, apartado que falta en el impreso mexicano. Fuera de eso, la información en la portada es prácticamente idéntica, con ciertas diferencias en el uso de mayúsculas, alternancias de u-v (con valor consonántico y vocálico, respectivamente), ${ }^{20}$ comas y saltos de líneas; incluso está presente el escudo de armas del rey Felipe $V$ en ambos casos.

La información de la "licencia" y la "suma" contienen el mismo texto y sólo se distinguen porque la edición mexicana tiene saltos de línea más frecuentes, seguramente debido a que el ojo de los tipos en la edición mexicana es más ancho que el de la española (Imágenes 3 y 4).

Así, la misma información se expresa en 5 líneas en la edición madrileña y en 6 en la mexicana para la "Suma de la Licencia y Privilegio", mientras que en la "Suma de la Tasa" son 6 y 7 líneas, respectivamente. Lo anterior pone en evidencia que es la edición mexicana la que imita a la madrileña, pues advertimos un desfase en el espacio utilizado, aunque se conserva la extensión para abarcar exactamente los 37 pliegos. El impreso de Paula de Benavides utiliza varias técnicas que compensan el desfase mencionado, por ejemplo el uso de abreviaturas ("P." por Padre) o la supresión de ciertas palabras o información, como en el caso del "Cotejo de la obra con el original", donde se explica para el impreso español "Este libro intitulado [...] con estas erratas corresponde con su original",

\footnotetext{
${ }^{20}$ Nos referimos a las diferencias de uso de u-v entre una edición y otra, y no a la alternancia de u-v como hábito común en el uso de dichas grafías durante el periodo de la imprenta manual.
} 
mientras que el impreso mexicano dice simplemente "Este libro intitulado [...] corresponde con su original".

La divergencia de saltos de línea se repite en todo el libro: en la página 98 hay tres líneas de diferencia entre las dos ediciones. Sin embargo, en otros momentos el desfase se restituye: en la página 3, de la línea 8 a la 16 el texto es el mismo, y para lograrlo se ha recurrido al uso de diversas abreviaturas (Imágenes 5 y 6). Señalamos que en el impreso mexicano se omite en los preliminares la "Fe de erratas", esto debido a que los errores de la edición madrileña se han corregido, lo cual reafirma que la imprenta de Paula de Benavides tomó como base algún ejemplar de la edición española de María de Quiñones.

De acuerdo con el desgaste de los materiales (iniciales grabadas y adornos tipográficos) puede aventurarse el año de impresión hacia 1648. Las iniciales grabadas utilizadas en la edición mexicana se aprecian bastante más desgastadas que las que aparecen en Arte mexicano de 1642 y en Crónica de la Orden de nuestro seráfico padre San Francisco de 1643, ligeramente menos desgastadas que en Auto general de la fee de 1649, y con un estado de desgaste similar al de la Imagen de la Virgen María, madre de Dios de Guadalupe de 1648, libros todos, por supuesto, impresos por la viuda de Calderón. A manera de ejemplo ponemos la inicial grabada "S", que en 1642 presenta una ligera fisura en la parte interna de la curva inferior (Imagen 7), en 1648 encontramos la misma fisura y, además, un nuevo daño en la parte central de la cima, a la izquierda de la cabeza de la serpiente (Imagen 8) y con estos dos deterioros la encontramos también en la edición De la devoción y patrocino de San Miguel (Imagen 9). ${ }^{21}$

El análisis material de las ediciones, sumado a la revisión de la tradición bibliográfica, 22 evidencia que la impresión mexicana a cargo de Paula de Benavides, además de imitar la edición madrileña, no cumple con los requisitos de las impresiones legales de la época. Es importante señalar que en otras ediciones la imprenta de Paula de Benavides trata de apegarse a la normativa vigente; ${ }^{23}$ por ejemplo, la obra Arte mexicano (1642) de Diego de Galdo Guzmán fue impresa

${ }^{21}$ En esta edición se nota mayor entintado, por ello en la reproducción no se distinguen los detalles de las líneas de adorno.

22 Por tratarse de un autor europeo, los catálogos de Juan José Eguiara y Eguren, Biblioteca mexicana, y de José Mariano Beristáin de Souza, Biblioteca hispano-americana septentrional, no incluyen esta obra.

${ }^{23}$ Nos referimos a un análisis parcial de los productos editoriales de la imprenta de Paula de Benavides, ya que hasta el momento no existe una tipobibliografía que recoja todos los apartados textuales de todas las ediciones publicadas en México durante el siglo XVII. 
con portada que incluía el título, nombres del autor e impresor, además de los siguientes preliminares: Licencia y privilegio firmado por el virrey Diego López Pacheco Cabrera y Bobadilla, Parecer de fray Jerónimo de Majuelo, Aprobación de Juan Rubio, de la orden de San Agustín; Licencia de impresión del doctor Pedro de Barrientos, consultor de la Inquisición, y la Aprobación del licenciado Luis Fonte de Mesa, cura de la parroquia de Veracruz. La obra Crónica de la orden de nuestro seráfico padre San Francisco (1643) del padre Alonso de la Rea tiene entre sus preliminares: Licencia y privilegio del virrey García Sarmiento de Sotomayor, Licencia inquisitorial firmada por fray Juan de Prada, comisario general, así como la Censura de fray Alonso Bravo de Lagunas. Recordemos que a partir de la Pragmática de 1558, para la regulación del libro en los virreinatos las licencias tenían que ser emitidas por el virrey y el arzobispo, además de que debían reproducirse junto con las aprobaciones y correcciones de los censores e inquisidores. En cambio, la edición mexicana motivo de este trabajo reproduce a pie juntillas los preliminares madrileños y no hace referencia a ningún tipo de autorización emitida en Nueva España.

Como sabemos, la principal motivación para que los impresores de la época burlaran las leyes impuestas a la producción de libros fue la intensa regulación que sufría la imprenta durante el Antiguo Régimen, la cual ocasionó que la producción de libros disminuyera drásticamente. Así que, de alguna forma, se vieron obligados a "obviar" las pragmáticas como estrategia para sostener el trabajo de las imprentas, situación que originó la existencia de varios tipos de impresos, según el cumplimiento o no de la regulación de la época. ${ }^{24}$

${ }^{24}$ En el ámbito hispánico durante el Antiguo Régimen, al igual que en Nueva España, se han identificado varios casos de ediciones ilegales; véanse Guadalupe Rodríguez Domínguez, "Una edición contrahecha de las Obras en prosa y verso de Jacinto Polo de Medina", Revista General de Información y Documentación 18 (2008): 323-341; Jaime Moll, "Novelas ejemplares, Madrid, 1614: Edición contrahecha sevillana", Anales Cervantinos 20 (1982): 125-133; Francisco Gutiérrez de los Ríos y Córdoba, conde de Fernán Núñez, El hombre práctico o discursos varios sobre su conocimiento y enseñanza, ed. de José Pérez Magallón y Russell P. Sebold (Córdoba: Obra Social y Cultural Caja Sur, 2000). Para el ámbito novohispano también existen estudios sobre la falta de legalidad de algunas ediciones, véanse Guadalupe Rodríguez Domínguez, "Asignación de imprentas y años de publicación de las ediciones del Viaje de América a Roma, de José de Castro: valoración para su edición crítica", Zeitschrift für Romanische Philologie 133, núm. 2 (2017): 472-491, y de la misma autora: "Las Doctrinas cristianas de la Orden de Santo Domingo impresas en México en el siglo XVI, ¿ediciones contrahechas?", Revista Complutense de Historia de América, de próxima aparición. 
Jaime Moll ha descrito una tipología del libro durante el Antiguo Régimen, en la que distingue dos grandes grupos: las ediciones legales y las ilegales. Las primeras son las elaboradas conforme los requisitos de la legislación de imprenta vigente en la época y el territorio en donde se lleva a cabo la edición, mientras que las ilegales no cumplen con dicha regulación y burlan uno o varios de los requisitos..$^{25}$

Entre las ediciones ilegales, Moll identifica cinco tipos: edición sin licencias, edición falsificada, edición contrahecha, edición pirata y edición subrepticia. Sobre la edición contrahecha ofrece la siguiente explicación:

Reedición, que intenta suplantar una edición legal preexistente, de la que copia todos o parte de los datos del pie de imprenta y mantiene o cambia el año. Reproduce, textual o abreviadamente, los preliminares exigidos por la ley, que figuran en la edición que ha servido de modelo. Pueden ser producidas por el mismo editor, en años posteriores a la edición legal. En algunos casos imitan al máximo la edición modelo. Es frecuente eliminar de la portada el nombre del librero-editor y en algunos casos se cambia por el del librero que editó la edición contrahecha. Si el año es posterior al de la edición modelo, es muy probable que sea el de la edición contrahecha. ${ }^{26}$

La edición mexicana salida de la imprenta de Paula de Benavides cumple con varias de las características de las ediciones contrahechas identificadas por Moll: "reproduce, textual o abreviadamente, los preliminares exigidos por la ley", "imita al máximo la edición modelo", "elimina de la portada el nombre del librero-editor", etcétera. Todo indica que esta edición mexicana trató de suplantar la edición legal de Devoción y patrocinio de San Miguel impresa en 1643 por María de Quiñones en Madrid.

Ha quedado dilucidado que la edición de Paula de Benavides es posterior a la madrileña, pero la impresora no deja constancia de ello, sino que omite toda información respectiva a la fecha. Asimismo, reproduce textualmente dos de los preliminares: la "Suma de la licencia y privilegio" y la "Suma de la tasa", incluye parcialmente el cotejo y omite la "Fe de erratas"; copia literalmente el texto y ajusta la composición para que al final se utilicen exactamente 37 pliegos (cuestión fundamental para poder conservar la tasa); cambia el nombre del

25 Jaime Moll, Problemas bibliográficos del libro del Siglo de Oro (Madrid: Arco/Libros, 2011), 50 .

26 lbid., 53-54. 
editor (a viuda de Bernardo de Calderón), así como el lugar: "[véndese] en la calle de San Agustín".

No olvidemos que la existencia de ediciones ilegales estaba motivada principalmente por razones comerciales, ya que la evasión del trámite de las licencias, aprobaciones, censuras, etcétera, ahorraba considerables recursos financieros a los impresores. En este sentido, se sabe que Paula de Benavides era una mujer con grandes cualidades empresariales y había aprendido de su esposo el arte de la negociación. ${ }^{27}$ Ejemplo de ello es que Bernardo de Calderón había conseguido el 12 de septiembre de 1631 un permiso exclusivo para la impresión y venta de cartillas por parte del virrey marqués de Cerralvo, ${ }^{28}$ y a cambio tenía la obligación de dar: "seis libros sueltos o encuadernados, imprimir todos los despachos del servicio de su majestad y poner papel para ello, incluyendo además 100 pesos de limosna al Hospital Real de la ciudad durante seis años, de lo contrario se le multaría con 100 pesos y la pérdida de los moldes". ${ }^{29}$

A pesar de las obligaciones, el contrato para la impresión y venta exclusiva de cartillas era muy redituable, pues eran el instrumento principal para enseñar a leer y escribir, al tiempo que servían para reafirmar la fe católica; por otra parte, su uso cotidiano las desgastaba muy pronto, así que su venta era segura y su impresión constante. Sin embargo, a la muerte de Bernardo de Calderón a finales de 1640 el permiso concedido quedó en el aire. En enero de 1641 Francisco Robledo solicitó la licencia de impresión de cartillas. Fue entonces cuando Paula de Benavides, como toda una visionaria, se apresuró a realizar las gestiones para que se le refrendara el privilegio de venta e impresión de las cartillas. Presentó varias razones para que se lo otorgaran, como el cumplimiento de su marido al contrato, su propia obligación de sustentar a seis hijos, la imprenta y la librería en la calle de San Agustín, además de que ofrecía mayores contribuciones por dicho privilegio. Parece que por todo eso las autoridades la beneficiaron sin dilatar mucho: "Atento a las causas que presenta y [al] crecimiento de su

\footnotetext{
${ }^{27}$ Marina Garone le dedica el apartado "Mujeres de la dinastía de los Calderón, Benavides y Rivera", en el que hace una breve revisión de los estudios realizados sobre la labor de estas mujeres impresoras. Marina Garone Gravier, "Impresoras hispanoamericanas: un estado de la cuestión", Bulletí de la Reial Acadèmia de Bones Lletres de Barcelona 51 (20072008): 460-461.

${ }^{28}$ Ana Cecilia Montiel Ontiveros y Luz del Carmen Beltrán Cabrera, "Paula de Benavides: impresora del siglo XVII. El inicio de un linaje", Contribuciones desde Coatepec, núm. 10 (2016): 106.

29 Ibid., 107.
} 
postura, por el presente mando que dicha Paula de Benavides se haga asiento por un lapso de seis años". ${ }^{30}$

Paula de Benavides defendió vehementemente su privilegio, ya que en octubre de 1641 presentó una querella en contra de Francisco Robledo y Juan Ruiz, también impresores, "para que no impriman ni vendan por sí ni por terceras personas cartillas con pretexto de llamarlas doctrinas o catecismos". ${ }^{31}$ Ruiz y Robledo replicaron que el privilegio de la viuda no se extendía a las doctrinas en lengua mexicana, sino que se reducía a las cartillas en castellano para la enseñanza de dicha lengua. Juan Ruiz solicitó un privilegio para que sólo él pudiera imprimir y vender doctrinas, pero las autoridades resolvieron que "[él] no debía imprimir ni vender cartillas con el pretexto de llamarlas doctrinas o catecismos, y que las existentes deberían ser entregadas a Paula de Benavides, a pesar de las razones que había expuesto". ${ }^{32}$

Lo anterior denota que la viuda de Calderón era una mujer astuta para los negocios y sabía buscar el mayor beneficio empresarial, así que puede colegirse que la obra del padre Nieremberg, De la devoción y patrocinio de San Miguel, sería un libro redituable y con gran aceptación por parte del público, lo suficiente para justificar una edición ilegal que le ahorrara el tiempo y los recursos destinados a la tramitación de los permisos de impresión. No olvidemos que todo indica que al menos hasta 1647 la imprenta de Benavides no tenía problemas con la producción, ya que aún gozaba de la exclusividad de impresión de las cartillas. Tal como señala Fermín de los Reyes Gómez: "las dificultades por los trámites administrativos y la competencia mercantil, motivaron la realización de numerosas ediciones ilegales. Si a ello se une la facilidad de evitar las diligencias, tenemos un siglo repleto de ilegalidades". ${ }^{33}$ Pareciera que más que por motivos administrativos o de poca producción en la imprenta, la viuda de Calderón decidió hacer una edición ilegal de dicho libro porque su impresión le traería importantes beneficios económicos.

Por sus características -y según la tipificación de la edición ilegal propuesta por Moll- el impreso De la devoción y patrocinio de San Miguel de Paula de Benavides se ubica entre las ediciones contrahechas, pero habría que considerar que si el privilegio del padre Nieremberg aplicaba durante 10 años para todo el reino español y Paula de Benavides hizo la impresión durante ese perio-

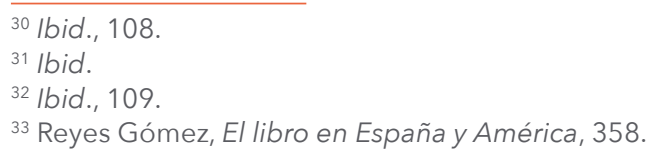


do, entonces el resultado sería también una edición pirata: "edición hecha, en periodo de vigencia de un privilegio y dentro de su ámbito territorial, por persona ajena a dicho privilegio y con datos tipográficos auténticos", ${ }^{34}$ aunque Moll señala que este tipo de ediciones eran escasas en España durante los siglos XVI y XVII. Sin embargo, de acuerdo con la normativa se consideraría edición legal si el poseedor del privilegio, el padre Nieremberg, lo hubiera cedido para realizar la edición en Nueva España pero, en ese caso, debía figurar en los preliminares dicha cesión. ${ }^{35}$

Como hemos visto, no sucede así, de modo que, a todas luces, se trata de una práctica ilegal en términos exclusivamente administrativos y civiles. Habría que considerar que este tipo de prácticas editoriales no eran perseguidas por la Inquisición, debido a que su ilegalidad reside en la falta de preliminares preceptivos por la ley, como señala Moll, que eran competencia de la autoridad civil. La Inquisición se centraba, sobre todo, en la persecución y expurgo de textos que contuvieran ideas "peligrosas" o en contra de la religión católica. Lo cual no se pone en duda para esta investigación, ya que la obra De la devoción y patrocinio de San Miguel sí contiene una censura del padre Juan de Cantabrana, calificador del Consejo Supremo, y la aprobación del padre Agustín de Castro, de la Compañía de Jesús, ambos religiosos residentes de la metrópoli.

En este orden de ideas, como bien apuntan Marta Milagros del Vas Mingo y Miguel Luque Talaván, tras el Concilio de Trento fueron prohibidas las obras que presentaran alguna de las siguientes circunstancias:

que fueran contra la fe católica; que versaran sobre nigromancia, astrología o promoviesen la superstición; que fueran indecentes o que atentasen contra las normas morales católicas -aquellas imágenes, medallas y otros objetos que poseyesen alguna de las características citadas eran igualmente prohibidas-; que no tuvieran licencia de impresión, nombre de autor o del impresor, ni demás referencias de la edición (lugar y fecha); y que vulneraran el honor de las personas -fueran laicas o eclesiásticas- o agrediesen a las instituciones eclesiásticas o a príncipes temporales. ${ }^{36}$

\footnotetext{
${ }^{34}$ Moll, Problemas bibliográficos, 59.

$35 \mathrm{lbid}$.

${ }^{36}$ Marta Milagros del Vas Mingo y Miguel Luque Talaván, "El comercio librario: mecanismos de distribución y control de la cultura escrita en Indias", Revista Complutense de Historia de América 32 (2006): 132.
} 
Estos autores también señalan que existía una pena establecida para el incumplimiento de la normativa, ya que "transgredir la licencia de impresión se castigaba con la pérdida de los libros impresos ilegalmente y también con la pérdida de los aparejos de imprenta llegando incluso hasta el destierro". El incumplimiento de las normativas referentes al libro por parte de impresores y/o libreros, se hace patente por los constantes esfuerzos de la Corona y la Iglesia para controlar el flujo de las obras impresas: "es reseñable la reiteración de las leyes en el siglo XVII por tratar de parar el fraude de imprimir y distribuir libros sin licencia". ${ }^{37}$

Si bien parece que la viuda de Calderón se exponía a grandes riesgos al hacer una edición ilegal, este asunto no era tan grave, pues siempre podía recurrirse a la excusa de la ignorancia y a la costumbre, que era algo frecuente en el periodo, como explica Reyes Gómez:

Hay constancia de que, a veces, los impresores no actúan de mala fe, sino por desconocimiento de la legislación, o al menos eso dicen con frecuencia. Lo excepcional es que un tipógrafo se interese por ella sin estar incurso en un proceso. Así ocurrió en Nueva Guatemala, donde el impresor Ignacio Beteta, en 1787, dice desconocerla, al igual que su antecesor, Antonio Sánchez Cubillas, actuando por la costumbre, que es la siguiente:

- Una obra se puede reimprimir sin otra licencia que la del original de donde se reimprime, quedando éste en la oficina para su comprobación.

- Toda obra nueva ha de tener permiso del Superior Gobierno y Eclesiástico. Si son novenas u otras devociones cortas, tan solo el del Eclesiástico.

- Las tarjas de conclusiones de la Universidad, con la licencia del rector, que las revisa antes de darlas.

- Los calendarios, cuadernillos o directorios de rezo, guías para las administraciones reales, estados mensuales, convites, décimas para pedir limosnas, patentes de cofradías, etc., sin licencia. ${ }^{38}$

\footnotetext{
${ }^{37}$ Ibid., 136.

${ }^{38}$ Reyes Gómez, El libro en España y América, 694.
} 


\section{Conclusiones}

El mensaje del padre Nieremberg versa sobre las excelencias del arcángel san Miguel y presenta todos los títulos que posee: Príncipe de los Ángeles, Vicario de Cristo, vice-Dios, etcétera; expone, además, razones que explican su importancia para el reino español, como el hecho de que cuando los godos se convirtieron al catolicismo fue un día de san Miguel, y en la invasión de España por los árabes primero acudieron al patrocinio de éste que al de Santiago, de tal manera que san Miguel fue reconocido como protector de los españoles antes que Santiago. También explica que dicho santo está a cargo de la Iglesia por mandato divino y como España es un miembro tan principal, debe recibir como protector de su imperio al que Dios dio por toda su Iglesia. Es por ello que los españoles deben implorar su patrocinio y confiar en que les ha de amparar, pues España ha expandido la religión católica en muchas partes del mundo y la ha defendido en Alemania, Flandes y Francia con grandes gastos suyos, por lo que tiene mayor derecho a la protección de san Miguel.

Por todo lo expuesto podemos concluir que la impresora Paula de Benavides apostó a la publicación de una edición contrahecha de esta obra con buena recepción en España, lo cual le aseguraba tanto su aceptación en Nueva España como un ingreso exento de los gastos de tramitación de los permisos preceptivos; además, en caso de ser detectada la ilegalidad, siempre podía apelar al desconocimiento de la ley o a los usos y costumbres editoriales de época. En este sentido, la práctica de la publicación de ediciones ilegales, considerando la ilegalidad en términos técnicos de la legislación vigente del libro impreso, pudo haber sido tolerada por las autoridades competentes. No obstante, ésta es una posibilidad que no ha sido demostrada por ninguna investigación hasta el momento.

Existen, seguramente, más especímenes editoriales con características similares que no han sido identificados aún; queda mucho por investigar sobre la imprenta novohispana, pero de momento con este trabajo aportamos un elemento más para ir completando paulatinamente el fragmentado panorama de la historia del libro mexicano impreso. 


\section{Referencias}

Aguilera Murguía, Ramón y Xóchitl Martínez Barbosa. "Libros, inquisición y devoción". En Inquisición novohispana. Vol. 33. Edición de Noemí Quezada, Martha Eugenia Rodríguez y Marcela Suárez, 361-378. México: Universidad Nacional Autónoma de México, 2000.

Andrade, Vicente de Paula. Ensayo bibliográfico mexicano del siglo XVII. México: Imprenta del Museo Nacional, 1899.

Bello Fuentes, Yolanda Remedios. "Impresores y sus obras en el siglo XVII: Bernardo Calderón y Paula de Benavides, viuda de Bernardo Calderón, 1631 1684". Tesis de maestría. Universidad Nacional Autónoma de México, 2011. http://132.248.9.195/ptd2011/diciembre/0675760/Index.html.

Biblioteca Histórica de la Universidad Complutense de Madrid "Marqués de Valdecilla".

Biblioteca Nacional de México. Nautilo, catálogo de la Biblioteca y Hemeroteca Nacionales de México. Universidad Nacional Autónoma de México.

Delgado Casado, Juan. Diccionario de impresores españoles (siglos XVI-XVII). 2 vols. Madrid: Arco/Libros, 1996.

Garone Gravier, Marina. "Impresoras hispanoamericanas: un estado de la cuestión". Bulletí de la Reial Acadèmia de Bones Lletres de Barcelona 51 (20072008): 451-471.

Gutiérrez de los Ríos y Córdoba, Francisco, conde de Fernán Núñez. El hombre práctico o discursos varios sobre su conocimiento y enseñanza. Edición de José Pérez Magallón y Russell P. Sebold. Córdoba: Obra Social y Cultural Caja Sur, 2000.

Medina, José Toribio. La imprenta en México (1539-1821). Tomo III. Santiago de Chile: En casa del autor, 1907.

Moll, Jaime. "Novelas ejemplares, Madrid, 1614: Edición contrahecha sevillana". Anales Cervantinos 20 (1982): 125-133.

Moll, Jaime. Problemas bibliográficos del libro del Siglo de Oro. Madrid: Arco/ Libros, 2011.

Montiel Ontiveros, Ana Cecilia y Luz del Carmen Beltrán Cabrera. "Paula de Benavides: impresora del siglo XVII. El inicio de un linaje". Contribuciones desde Coatepec, núm. 10 (2016): 103-115. Acceso el 26 de junio de 2019. http://hdl.handle.net/20.500.11799/38764.

Ramos Soriano, José Abel. Los delincuentes de papel: Inquisición y libros en la Nueva España (1571-1820). México: Fondo de Cultura Económica, 2011. 
Reyes Gómez, Fermín de los. El libro en España y América: legislación y censura, siglos XV-XVIII. Madrid: Arco/Libros, 2000.

Rodríguez Domínguez, Guadalupe. "Asignación de imprentas y años de publicación de las ediciones del Viaje de América a Roma, de José de Castro: valoración para su edición crítica". Zeitschrift für Romanische Philologie 133, núm. 2 (2017): 472-491.

Rodríguez Domínguez, Guadalupe. "Las Doctrinas cristianas de la Orden de Santo Domingo impresas en México en el siglo XVI, ¿ediciones contrahechas?". Revista Complutense de Historia de América. De próxima aparición.

Rodríguez Domínguez, Guadalupe. "Una edición contrahecha de las Obras en prosa y verso de Jacinto Polo de Medina". Revista General de Información y Documentación 18 (2008): 323-341.

Rodríguez Ortega, Davinia. "Heredera de Pedro Madrigal: María de Quiñones, impresora de ingenios áureos". Estudos Ibero-Americanos 42, núm. 3 (2016): 1066-1094. DOI: http://dx.doi.org/10.15448/1980-864X.2016.3.25853.

Utrera Bonet, María del Carmen. "La pragmática del 1558 sobre impresión y circulación de libros en Castilla a través de los fondos de la Biblioteca de la Universidad de Sevilla". En Funciones y prácticas de la escritura: I Congreso de Investigadores Noveles en Ciencias Documentales. Coordinación de Juan Carlos Galende Díaz, 277-281. Madrid: Universidad Complutense de Madrid, 2013.

Vas Mingo, Marta Milagros del y Miguel Luque Talaván. "El comercio librario: mecanismos de distribución y control de la cultura escrita en Indias". Revista Complutense de Historia de América 32 (2006): 127-148.

Ward, Kenneth C. "'Mexico, where They Coin Money and Print Books': The Calderón Dynasty and the Mexican Book Trade, 1630-1730". Tesis de doctorado. Universidad de Texas, 2013. http://hdl.handle.net/2152/26062. bg 